\title{
Laccase-Catalyzed Bioelectrochemical Oxidation of Water Assisted with Visible Light.
}

\author{
Cristina Tapia ${ }^{\mathrm{a}}$, Sergey Shleev ${ }^{\mathrm{b}}$, Jose Carlos Conesa ${ }^{\mathrm{a}}$, Antonio L. De Lacey ${ }^{\mathrm{a}^{*}}$, Marcos Pita ${ }^{\mathrm{a}^{*}}$. \\ ${ }^{a}$ Instituto de Catálisis y Petroleoquímica, CSIC. C/ Marie Curie, 2. L10 28049 Madrid, Spain. \\ ${ }^{b}$ Biomedical Sciences, Faculty of Health and Society, Malmo University, SE-0205 06 Malmo, Sweden. \\ KEYWORDS : photocatalysis, biocatalysis, laccase, water splitting, oxygen, visible light.
}

DIGITAL CSIC version. Originally published at ACS Catalysis 2017, 7, 4881-4889: DOI 10.1021/acscatal.7b01556

\begin{abstract}
Here we present the modification of fluorinated tin oxide electrodes with $\operatorname{In}_{2} \mathrm{~S}_{3}$, a n-type semiconductor chalcogenide that absorbs visible light $(\lambda \leq 600 \mathrm{~nm})$, and its further use as an active scaffold for laccase-catalyzed oxidation of water. Illumination of FTO- $\mathrm{In}_{2} \mathrm{~S}_{3}$-laccase electrode yields $\mathrm{O}_{2}$ production at much lower applied potential than the previous example using the same laccase, where only electric energy was applied. The present system allows a diversification of the energy applied to accomplish the water splitting, taking a portion of it from the Sun. This work is the first example where an enzyme other than PSII has been used combined with visible light to biocatalyze the $\mathrm{O}_{2}$ evolution.
\end{abstract}

\section{Introduction}

Solar and wind energies, which play an increasingly important role for a sustainable development, suffer of an intermittency problem which demands some sort of storage. One way to solve it is to capture $\mathrm{CO}_{2}$ or decompose water through processes such as

$$
n \mathrm{CO}_{2}+\mathrm{m} \mathrm{H}_{2} \mathrm{O} \rightarrow \mathrm{C}_{\mathrm{n}} \mathrm{H}_{2 \mathrm{~m}} \mathrm{O}_{\mathrm{p}}+(\mathrm{n}+(\mathrm{m}-\mathrm{p}) / 2) \mathrm{O}_{2}
$$

or

$$
\mathrm{H}_{2} \mathrm{O} \rightarrow \mathrm{H}_{2}+1 / 2 \mathrm{O}_{2}
$$

This allows storing energy as fuel. In the case of solar energy these processes are usually named solar fuel generation or artificial photosynthesis, and were revealed as possible for the first time by work by Fujishima and Honda in the early seventies ${ }^{1,2}$ showing that water could be split in $\mathrm{H}_{2}$ and $\mathrm{O}_{2}$ using a $\mathrm{TiO}_{2}$ photoelectrode. Because of the importance and potential of the concept many reviews ${ }^{3-7}$ have been devoted to this subject. Photoelectrochemistry has advantages against pure photocatalysis, since it facilitates the fuel and $\mathrm{O}_{2}$ production in separate compartments (avoiding thus their recombination); and also against photovoltaics+electrolysis as it may diminish the energy losses due to the lower number of interfaces that charge carriers must go through. Furthermore, electrochemistry and photoelectrochemistry of semiconductors had already been deeply studied, ${ }^{8-11}$ building a sound scientific basis to understand and develop that technology. The study of photocatalysis by oxides had begun much earlier ${ }^{12}$ and provides additional knowledge on the surface chemistry involved.

The production of solar fuels needs a compound able to capture solar light and separate the photogenerated positive (holes) and negative (electron) charges so that chemistry can be made from them. Besides, the resulting redox levels must have potential enough to produce the desired chemistry. For water splitting the potential difference must be higher than
$1.23 \mathrm{~V}\left(E_{0}\right.$ for $\mathrm{O}_{2}$ evolution at $\left.\mathrm{pH}=0\right)$, implying that those energy levels should be separated by a significant extra energy to overcome the energy losses; in addition, the excited electrons should appear at energy higher than the $\mathrm{H}_{2}$ evolution redox potential, and the holes at energies lower than the $\mathrm{O}_{2}$ evolution redox potential. Many light absorbers i.e. molecular entities or polymers have been proposed and reviewed ${ }^{5,13-15}$. Here we focus on semiconducting light absorbers with bandgap energy $\mathrm{E}_{\mathrm{g}} \geq 1.7 \mathrm{eV}$. $\mathrm{TiO}_{2}$ (rutile or anatase) is the best-known photocatalyst and photoelectrode: is stable, affordable and highly photoactive; however its large bandgap $\left(E_{\mathrm{g}}=3.0-3.2 \mathrm{eV}\right)$ limits $\mathrm{TiO}_{2}$ to UV light, disregarding $\geq 95 \%$ of the solar spectrum. Huge efforts have been driven toward other materials able to use efficiently visible light. These include $\mathrm{TiO}_{2}$ doped with cations $(\mathrm{Cr}, \mathrm{V}, \mathrm{Fe})$ or anions $(\mathrm{N}$ or $\mathrm{S})$; oxides like $\mathrm{BiVO}_{4}, \mathrm{Cu}_{2} \mathrm{O}, \mathrm{WO}_{3}$ or $\mathrm{Fe}_{2} \mathrm{O}_{3}$; nitrides or oxinitrides like $\mathrm{Ta}_{3} \mathrm{~N}_{5}, \mathrm{TaON}$, the perovskites $\mathrm{LaTiO}_{2} \mathrm{~N}$ and $\mathrm{LaN}-$ $\mathrm{bON}_{2}$ or two-dimensional g- $\mathrm{C}_{3} \mathrm{~N}_{4}$; or sulphides like $\mathrm{CuGaS}_{2}$, $\mathrm{CdS}, \mathrm{In}_{2} \mathrm{~S}_{3}, \mathrm{ZnIn}_{2} \mathrm{~S}_{4}, \mathrm{SnS}_{2}$ or $\mathrm{MoS}_{2}$ although the mentioned sulphides and some of the nitrides are prone to photooxidation during solar fuel generation, needing coverage with protecting oxide layers and/or co-catalysts able to extract holes efficiently. Photon harvesting semiconductors have been frequently reviewed, and we refer the reader to those works. ${ }^{3,4,6,16-18}$

Both reactions (1) and (2) release $\mathrm{O}_{2}$ molecules, thus extract electrons from water to form $\mathrm{O}-\mathrm{O}$ bonds. This oxygen electroevolution reaction (OER) is kinetically much more demanding than the generation of $\mathrm{H}_{2}$ itself (even though the latter is the interesting product), due to the need of coordinated transfer of 4 electrons and 4 protons as well as oxygen atoms transport (heavier than $\mathrm{H}$ ), which in addition bear higher electrostatic charges; thus the electrochemical overpotentials needed are relatively large. Efficient co-catalysts may facilitate such electrochemical process. Oxides like $\mathrm{RuO}_{2}$ and $\mathrm{IrO}_{2}$ 
are rather efficient but scarce and expensive elements cocatalysts in acid medium, ${ }^{19-23}$ Under alkaline conditions some common metal oxides are an alternative. ${ }^{24}$ Among them oxidized nickel, known to exist under working conditions as a relatively ill-crystallized oxyhydroxide containing $\mathrm{Ni}^{3+}$, is recognized as a rather good OER catalyst, in particular when including some iron as detected long ago by Corrigan ${ }^{25}$ and thoroughly verified recently; ${ }^{26}$ the best OER catalyst to date might be the amorphous $\mathrm{Fe}-\mathrm{Co}-\mathrm{W}$ oxide reported by Zhang et al., $^{27}$ for which the overpotential required to reach a current density of $10 \mathrm{~mA} / \mathrm{cm}^{2}$ (the parameter normally used to assess OER efficiency) is as low as $191 \mathrm{meV}$. Other materials reported are the cobalt phosphates proposed for the "artificial leaf",28 or cobalt poly-oxometalates; ${ }^{29}$ also, manganese and copper oxides or coordination complexes have been proposed ${ }^{30-33}$ inspired on the active centres of the natural enzymes known to catalyze efficiently the complete transformation between $\mathrm{O}_{2}$ molecules and water: photosystem II, which facilitates OER in natural photosynthesis, and laccases, which reduce $\mathrm{O}_{2}$ all the way to water without stopping the reaction at the $\mathrm{H}_{2} \mathrm{O}_{2}$ stage. In these cases the co-catalysts are arranged as nanoparticles, clusters or molecular complexes deposited on the surface of the light absorbing semiconductor, and must have electronic levels lower than the $\mathrm{O}_{2}$ redox potential but higher than the valence band of the semiconductor so that holes photogenerated at the latter may be transferred efficiently to water or $\mathrm{OH}^{-}$ groups at the co-catalyst-liquid interface.

As there are enzymes able to mediate the electrochemical conversion between water and $\mathrm{O}_{2}$, such enzymes may also work as co-catalysts. Indeed several works have tried to immobilize photosystem II (PSII) on electrodes. PSII is a multisubunit enzyme that performs solar light-driven $\mathrm{H}_{2} \mathrm{O}$ oxidation in photosynthetic organisms. This protein complex contains, besides the photosensitive centres that absorb visible light and the cofactors in which charge formation and separation takes place, a $\mathrm{Mn}_{4} \mathrm{CaO}_{5}$ cluster where the OER is catalyzed. ${ }^{34}$ Therefore, as reported by several research groups, when attached to an electrode the PSII can replace both photon absorbing substance and electrocatalyst to achieve the photoelectrochemical $\mathrm{H}_{2} \mathrm{O}$ oxidation. ${ }^{35-37}$ However, in these cases the PSII was immobilized on the electrode either within a conductive polymer or in presence of a redox mediator in the electrolyte in order to transfer the electrons from the catalytic site of PSII to the electrode surface. ${ }^{35-37}$ The reason is that the large size, high structural complexity, and fragile stability of PSII, when isolated from its natural environment in the cellular membrane, do not favour fast direct electron transfer, as has been done with simpler metalloenzymes. ${ }^{38,39}$ Kato et al. have reported direct electron transfer of PSII by a covalent oriented immobilization of the enzyme on an indium tin oxide electrode (ITO) modified with a self-assembled monolayer, ${ }^{40}$ but the photocurrent densities measured were two orders of magnitude smaller than those obtained by the same group, when the enzyme was wired to a ITO electrode by redox polymers. ${ }^{37}$

In a previous work we showed that the above mentioned copper-containing laccase enzymes, the natural activity of which is the 4-electron reduction of $\mathrm{O}_{2}$ in moderately acidic aqueous solutions, could catalyze the reverse reaction when forced under certain conditions. ${ }^{41}$ Laccases contain $4 \mathrm{Cu}$ atoms distributed in two different sites of the enzyme: (i) the T1 site, which contains one $\mathrm{Cu}$ ion coordinated to 3 or 4 amino acid residues, is near the protein surface and in the $\mathrm{O}_{2}$ reduction process receives the electrons from the donor compound dur- ing the catalytic reaction; (ii) the $\mathrm{T} 2 / \mathrm{T} 3$ site, which is formed by a cluster of $3 \mathrm{Cu}$ ions and is the catalytic centre for the 4electron reduction of $\mathrm{O}_{2}$ to $\mathrm{H}_{2} \mathrm{O}$. An intramolecular electron pathway connects the $\mathrm{T} 1$ and $\mathrm{T} 2 / \mathrm{T} 3$ sites and there are also channels for $\mathrm{O}_{2}$ and $\mathrm{H}_{2} \mathrm{O}$ transport between the protein surface and the T2/T3 cluster. $^{42}$ Laccases are classified according to the redox potential of their T1 site. ${ }^{43}$ The laccases with a high redox potential $\mathrm{T} 1$ site, which are of fungal origin, are very interesting for electrocatalytic applications because they are able to reduce oxygen at potentials above or near $0.7 \mathrm{~V}$ vs. SHE by direct electron transfer, produce high catalytic current densities and have high operational stability. ${ }^{44-49}$ The catalytic activity of laccases is irreversible under the normal conditions of measurement, which are a $\mathrm{pH}$ value around 4 and either an electron donor compound or an electrode biased at a redox potential lower than that of its $\mathrm{T} 1$ site $(0.7-0.85 \mathrm{~V}$ for the high redox potential laccases). ${ }^{42,50}$ However, we have shown that a native and a mutant fungal laccases covalently attached to chemically modified graphite electrodes were capable of oxidizing $\mathrm{H}_{2} \mathrm{O}$ to $\mathrm{O}_{2}$ at neutral $\mathrm{pH}$, when a high overpotential of $+1.2 \mathrm{~V}$ vs. SHE was imposed at the electrode. ${ }^{41}$

In the present work we show that the overpotential for water oxidation catalyzed by Trametes hirsuta laccase can be considerably decreased in a photoelectrochemical device comprising a hybrid inorganic/biological photocatalyst formed by laccase covalently bound to $\operatorname{In}_{2} \mathrm{~S}_{3}$ (Scheme 1). $\mathrm{In}_{2} \mathrm{~S}_{3}$ is a n-type semiconductor with a band gap $\mathrm{E}_{\mathrm{g}}=2.0 \mathrm{eV}$, well within the energy range of visible light radiation, and its valence band has an energy level lower than that required for oxygen evolution at neutral $\mathrm{pH}^{51,52} \mathrm{~A}$ photochemical study has revealed a carrier mobility value for $\operatorname{In}_{2} \mathrm{~S}_{3}$ that is in the same range as compounds frequently used in photoelectrodes, such as the metal oxides semiconductors $\mathrm{Cu}_{2} \mathrm{O}, \mathrm{WO}_{3}$ and $\mathrm{BiVO}_{4} \cdot{ }^{53,54} \mathrm{In}_{2} \mathrm{~S}_{3}$ has been tested as photoanode in aqueous media, but only rarely without a sacrificial agent ${ }^{55-57}$, so that $\mathrm{O}_{2}$ photogeneration may be feasible. However such works disregarded the photocorrosion or the generation of byproducts like $\mathrm{H}_{2} \mathrm{O}_{2}$, which have been evidenced ${ }^{58,59}$. Here we present a photoelectrochemical study of covalently-bound laccase molecules to $\mathrm{In}_{2} \mathrm{~S}_{3}$ particles deposited on transparent fluorinated tin oxide (FTO) electrodes for $\mathrm{O}_{2}$ evolution, detected with an appropriate sensor, under visible light illumination.

Scheme 1. Energy transfer diagram for the photo-assisted water oxidation bioelectrocatalytic process 


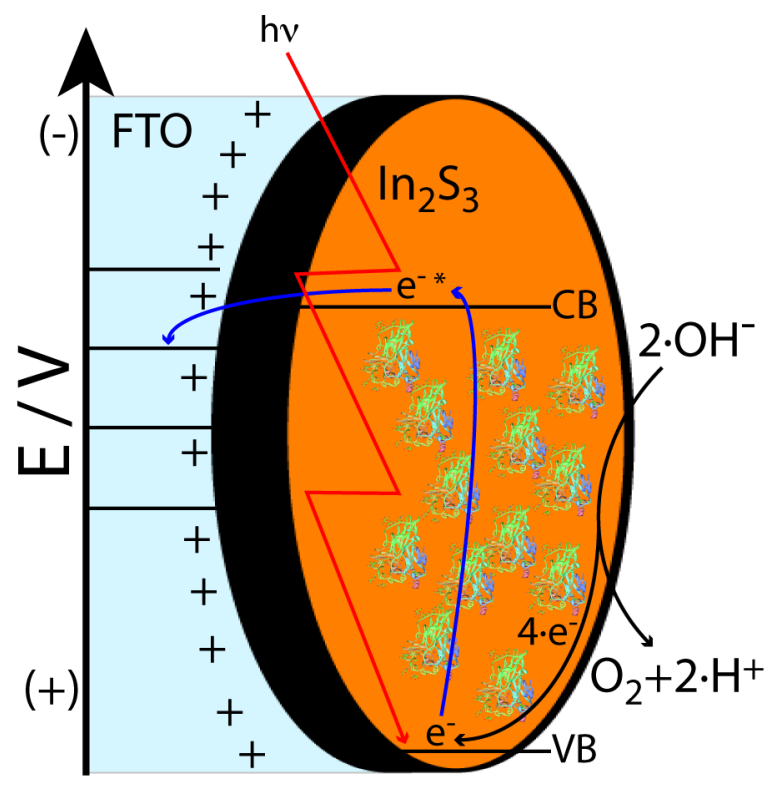

This is, to our knowledge, the first study on the photoanodic behavior of $\mathrm{In}_{2} \mathrm{~S}_{3}$ with an attached OER co-catalyst of any kind (inorganic or enzymatic), as well as the first work using a laccase as OER co-catalyst in a photoelectrochemical experiment.

\section{Experimental}

Reagents and materials. All the reagents were used as received without further purification. Di-sodium hydrogen phosphate 12-hydrate and sodium di-hydrate phosphate 2hydrate 99.0-102.0\% were purchased from Panreac. $\mathrm{InCl}_{3}$, Thiourea, 2,2'-Azino-bis (3-ethylbenzothiazoline-6-sulfonic acid) diammonium salt 98\% (ABTS), MES hydrate 99.5\%, 4nitrophenyldiazonium perchlorate, tetrabutylammonium tetrafluoroborate $99.0 \%$, sodium meta-periodate $99.8 \%$, n-(3dimethylaminopropyl)-n'-ethylcarbodiimide hydrochloride (EDC), Type I horseradish peroxidase $147 \mathrm{U} \cdot \mathrm{mg}^{-1}$ (HRP), and fluorine-doped tin oxide coated glass (FTO) were purchased from Sigma Aldrich. N-hydroxysuccinimide 97.0\% (NHS) was purchased from Fluka. Ethanol absolute 99.5\%, acetonitrile and acetone $99.5 \%$ were purchased from Scharlau. Aqueous solutions were prepared using MilliQ deionized water $(18.2 \mathrm{M} \Omega \times \mathrm{cm}) . \mathrm{O}_{2}(\mathrm{~g})$ and $\operatorname{Ar}(\mathrm{g})$ were purchased from Air Liquide. Grey dielectric paste was supplied by Gwent Group.

Trametes hirsuta laccase (ThLc), strain 56, was purified at Moscow State University of Engineering Ecology as previously reported ${ }^{60}$. HPLC and SDS-PAGE showed a homogeneous purification of the enzyme. The enzyme concentration was determined by the Bradford method ${ }^{61}$ using a Bio-Rad Laboratories kit with bovine serum albumin for calibration.

Synthesis of $\operatorname{In}_{2} S_{3}$. Polycrystalline $\beta-\operatorname{In}_{2} \mathrm{~S}_{3}$ was synthesized and characterized as reported previously ${ }^{62}$ following a known hydrothermal prodecure ${ }^{63}$.

Preparation of FTO- $\mathrm{In}_{2} \mathrm{~S}_{3}$ electrodes. 2 × $1 \mathrm{~cm}$ FTO electrodes were cleaned by immersion into water and 15 min ultrasound treatment. Afterwards the electrodes were washed with EtOH and immersed into acetone, applying again $15 \mathrm{~min}$ ultrasounds. The electrodes were further washed with EtOH, immersed into an EtOH solution and applied ultrasounds during $15 \mathrm{~min}$. The electrodes were let to dry. A copper wire was fixed to the FTO surface with conductive adhesive tape (Aris- ton), and finally the electrodes were masked with dielectric paste leaving exposed a $5 \mathrm{~mm}$ diameter circular FTO surface.

A $4 \mathrm{mg} \cdot \mathrm{mL}^{-1}$ suspension of $\operatorname{In}_{2} \mathrm{~S}_{3}$ in ethanol was prepared and subjected to ultrasounds during $20 \mathrm{~min}$. FTO electrodes were modified by dropping $7 \mu \mathrm{L}$ of the $\mathrm{In}_{2} \mathrm{~S}_{3}$ suspension and let to dry for $5 \mathrm{~min}$. The dropping-drying process was performed a total of 5 times and finally let to dry overnight (Fig. $1)$.

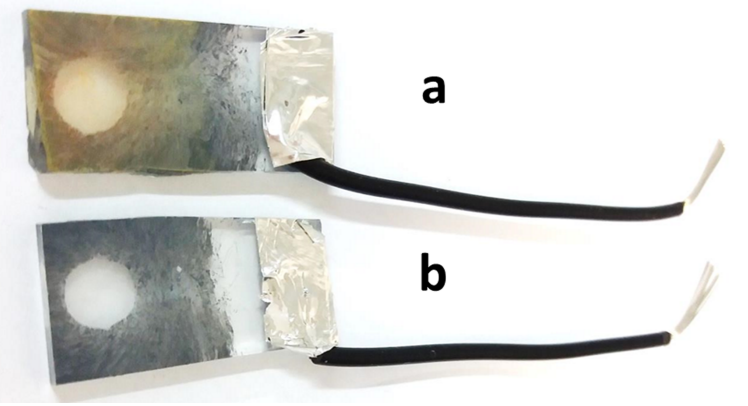

Figure 1. Photograph of (a) FTO- $\operatorname{In}_{2} \mathrm{~S}_{3}$ and (b) bare FTO electrodes.

X-Ray Diffraction (XRD) of FTO- $\mathrm{In}_{2} \mathrm{~S}_{3}$ electrodes was performed with a Philips X'Pert Pro PANalytical diffractometer $(\mathrm{Cu}-\mathrm{K} \alpha, \lambda=0.1541874 \mathrm{~nm})$. The samples were scanned from 4 to 90 degrees and the accumulation time was $20 \mathrm{~s}$. No pretreatment of the samples was needed.

Scanning electron microscopy (SEM) images of FTO- $\mathrm{In}_{2} \mathrm{~S}_{3}$ electrodes were obtained with a TM-1000 Tabletop Hitachi.

Trametes hirsuta laccase covalent immobilization on FTO$\mathrm{In}_{2} \mathrm{~S}_{3}$ electrodes. FTO- $\mathrm{In}_{2} \mathrm{~S}_{3}$ electrodes were immersed in a 3electrode electrochemical cell filled with $5 \mathrm{~mL}$ of $\mathrm{CH}_{3} \mathrm{CN}$ containing $2 \mathrm{mM}$ of 4-nitrophenyldiazonium perchlorate and $100 \mathrm{mM} \mathrm{Bu}_{4} \mathrm{NBF}_{4}$ as electrolyte. Electrochemical grafting of nitrophenyl groups to the FTO- $\mathrm{In}_{2} \mathrm{~S}_{3}$ electrodes was performed by recording two cyclic voltammograms (CVs) from 0.8 to 0.1 $\mathrm{V}$ vs. SHE at $100 \mathrm{mV} \mathrm{s}^{-1}$ scan rate. The modified electrodes were rinsed thoroughly with EtOH and taken into an electrochemical cell containing a 9:1 mixture of $\mathrm{H}_{2} \mathrm{O}: \mathrm{EtOH}$. Two CVs were recorded from 0.2 to $-1.2 \mathrm{~V}$ vs. SHE at $100 \mathrm{mV} \cdot \mathrm{s}^{-1}$ scan rate to reduce the pendant nitro phenyl groups to amino phenyl ones. $^{64}$

$3 \mu \mathrm{L}$ pH $6.0100 \mathrm{mM}$ phosphate buffer containing $5.8 \mathrm{mg}$ $\mathrm{mL}^{-1}$ ThLc were added to $33 \mu \mathrm{L}$ of $47 \mathrm{mM} \mathrm{NaIO}$ and let to incubate at $0{ }^{\circ} \mathrm{C}$ during $30 \mathrm{~min}$. Then, $54 \mu \mathrm{L}$ of $100 \mathrm{mM}$ phosphate buffer $\mathrm{pH} 7.1$ were added to the solution. $15 \mu \mathrm{L}$ of the resulting solution were deposited on the surface of an aminoaryl-modified FTO- $\mathrm{In}_{2} \mathrm{~S}_{3}$ electrode at room temperature and let to incubate for $45 \mathrm{~min}$. Afterwards, $13.5 \mu \mathrm{L}$ of $14 \mathrm{mM}$ EDC and $11.2 \mu \mathrm{L}$ of $21 \mathrm{mM}$ NHS were added to the electrode and let to react for $90 \mathrm{~min}$ at room temperature. After the reaction the electrode was rinsed with $100 \mathrm{mM}$ phosphate buffer $\mathrm{pH}$ 7.1 and taken to the photoelectrochemical cell for the measurements.

Trametes hirsuta laccase covalent immobilization on bare FTO electrodes. The process of functionalization and laccase attachment was equivalent to that described for FTO- $\operatorname{In}_{2} \mathrm{~S}_{3}$ electrodes but using clean unmodified FTO.

Trametes hirsuta laccase physical adsorption on FTO-In $\mathrm{I}_{2} \mathrm{~S}_{3}$ electrodes. $15 \mu \mathrm{L}$ of ThLc solution was deposited on the FTO$\mathrm{In}_{2} \mathrm{~S}_{3}$ electrode surface and let to adsorb for $120 \mathrm{~min}$. 
Preparation of FTO-In ${ }_{2} \mathrm{~S}_{3}$-CuSO $\mathrm{S}_{4}$ electrodes. $10 \mu \mathrm{L}$ of an aqueous solution containing dissolved $\mathrm{CuSO}_{4}\left(3 \mathrm{mg} \cdot \mathrm{L}^{-1}\right)$ were deposited on the FTO- $\operatorname{In}_{2} \mathrm{~S}_{3}$ surface and let to dry.

Electrochemical measurements. A three-electrode cell with an $\mathrm{Ag} / \mathrm{AgCl}(3 \mathrm{M} \mathrm{NaCl})$ reference electrode and a $\mathrm{Pt}$ wire counter electrode was used. The electrochemical cell was under Ar atmosphere and was surrounded by a refrigeration glass jacket connected to a thermostatic water recirculation system set at $30^{\circ} \mathrm{C}$. For all the electrochemical measurements the cell was filled with $30 \mathrm{~mL}$ of phosphate buffer $100 \mathrm{mM}$ at $\mathrm{pH}$ 7.1. The electrochemical measurements were controlled by a PG30 Autolab Potentiostat/Galvanostat from Ecochemie. The current density values are calculated considering the geometrical area of the electrodes $\left(0.196 \mathrm{~cm}^{2}\right)$. All electrochemical measurements have been repeated at least 4 times; the shown CVs and chronamperommetries correspond to typical results.

Illumination was carried out with a LOT Quantum Design 150W Xenon Lamp setting the output power at 8.5A. The light source was placed at $28 \mathrm{~cm}$ from the working electrode. UV radiation was filtered with either a $1 \mathrm{~mm}$ thick polycarbonate layer or optical filters from Andover Corporation: $450 \mathrm{~nm}$ band-pass filter, $\lambda \geq 400$ and $\lambda \geq 495$ cutoff filters. Light intensity was measured with a LP471 UVA Probe (315-400 $\mathrm{nm})$ and with a LP471 RAD Probe (400-1050 nm). 10 measurements were averaged both in front and behind the electrochemical cell (without the electrode present) for each case.

The $\mathrm{O}_{2}$ produced in the electrochemical cell was monitored with a low range oxygen microsensor from Unisense (Oxy Meter OX-NP-17180) placed at ca. $1.5 \mathrm{~mm}$ distance from the working electrode. It should be noted that working electrodes were measured only once each, afterwards they were disposed. All the results exposed have been performed at least 3 times, yielding the average values expressed in the tables.

$\mathrm{H}_{2} \mathrm{O}_{2}$ determination. The spectrophotometric determination of $\mathrm{H}_{2} \mathrm{O}_{2}$ was performed with a UV-2401 PC SHIMADZU spectrophotometer at $\lambda=414 \mathrm{~nm}$ following a known procedure. ${ }^{65}$ The measurements were carried out after mixing in a cuvette $890 \mu \mathrm{L}$ of sample, $100 \mu \mathrm{L}$ of $9.1 \mathrm{mM} \mathrm{ABTS}$ and 10 $\mu \mathrm{L}$ of $1 \mathrm{mg} \cdot \mathrm{mL}^{-1} \mathrm{HRP}$ and letting to react during $8 \mathrm{~min}$.

Trametes hirsuta laccase activity characterization. Laccase activity was determined by following ABTS oxidation at $\lambda=$ $414 \mathrm{~nm}$. The cuvette contained $2.25 \mathrm{~mL}$ of $100 \mathrm{mM}$ phosphate buffer $\mathrm{pH} 4.4,250 \mu \mathrm{L}$ of $9.1 \mathrm{mM}$ ABTS and the sample. For laccase in solution, increasing amounts of laccase were added to the cuvette. For electrode-attached laccase, the electrode was immersed in a cuvette side that did not interfere with the light path. For electrolyte-leaked laccase determination the electrolyte solution was concentrated by 3 cycles of centrifugation at $4000 \mathrm{~g}$ using Centricon $3 \mathrm{~K}$ filters. The concentrated solution was taken to $5 \mathrm{~mL}$ of $100 \mathrm{mM}$ phosphate buffer $\mathrm{pH}$ 4.4. $2.5 \mathrm{~mL}$ of the concentrate were used for UV-Vis determination with the proper amount of ABTS.

\section{Results}

The synthesized polycrystalline $\beta$ - $\operatorname{In}_{2} S_{3}$ showed an orangered color and its characterization has been reported previous$1 y .{ }^{62}$ The particles ranged from $50 \mathrm{~nm}$ to micron-size agglomerates as observed by SEM, had a $37.2 \mathrm{~nm}$ crystal domain size determined by XRD, a $2.1 \mathrm{eV}$ band gap, a specific area of 40.6 $\pm 0.3 \mathrm{~m}^{2} \mathrm{~g}$, a total pore volume of $0.168 \mathrm{~cm}^{3} \mathrm{~g}$, and an average pore width of $16.5 \mathrm{~nm}^{62}$
Additional characterization was done after modification of the FTO electrodes with $\operatorname{In}_{2} \mathrm{~S}_{3}$ particles. A clean sample of FTO, a FTO- $\mathrm{In}_{2} \mathrm{~S}_{3}$ electrode, and a FTO- $\mathrm{In}_{2} \mathrm{~S}_{3}$-ThLc electrode were visualized by SEM, Figure 2. As a result of the $\operatorname{In}_{2} \mathrm{~S}_{3}$ deposition on the FTO surface the roughness increased. A more dense coverage of FTO with $\operatorname{In}_{2} \mathrm{~S}_{3}$ was not tried to avoid multilayer coverage, which would hinder further electron transfer to the laccase. The further modification with the laccase did not yield any significant change at this scale, as expected, taking into account the much smaller size of laccase molecules ${ }^{66}$ than that of the $\operatorname{In}_{2} \mathrm{~S}_{3}$ particles.

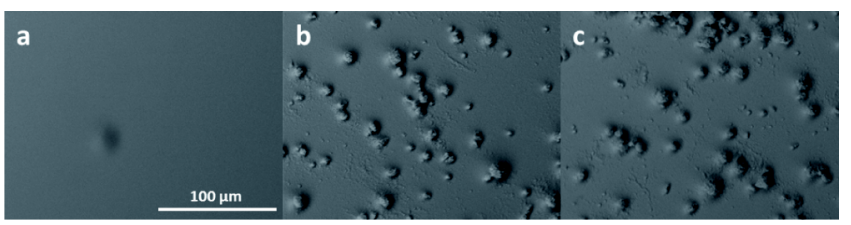

Figure 2. SEM images of (a) bare FTO, (b) FTO $\operatorname{In}_{2} \mathrm{~S}_{3}$, (c) FTO$\mathrm{In}_{2} \mathrm{~S}_{3}$-ThLc electrodes.

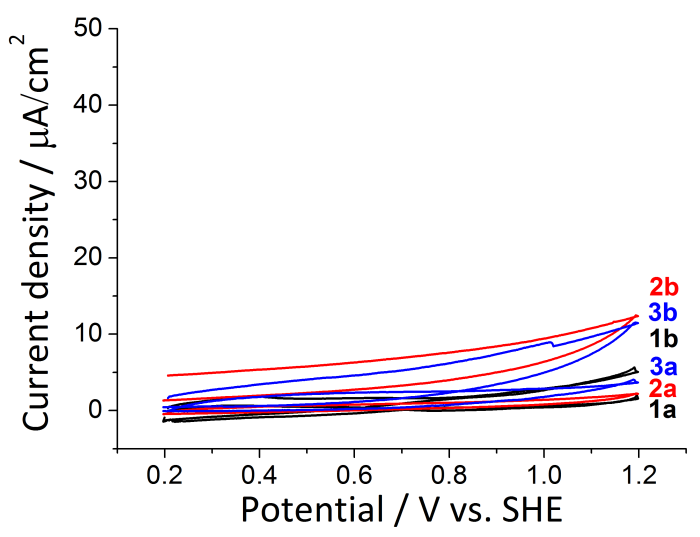

Figure 3 CVS of: bare FTO electrode dark (1a) and illuminated (1b); FTO-In $\mathrm{I}_{2} \mathrm{~S}_{3}$ electrode dar (2a) and illuminated (2b); FTO- $\mathrm{In}_{2} \mathrm{~S}_{3}$ electrode with physically adsorbed ThLc dark (3a) and illuminated (3b). Scan rate was $20 \mathrm{mV} / \mathrm{s}$.

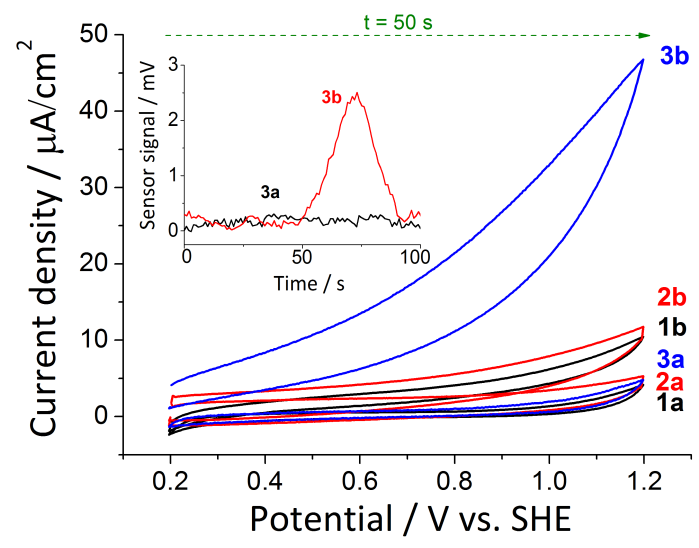

Figure 4. CVs of: FTO electrodes modified with covalently bound ThLc measured in dark (1a) and under illumination (1b); FTO modified with $\mathrm{In}_{2} \mathrm{~S}_{3}$ and functionalized with amino phenyl groups dark (2a) and illuminated (2b); FTO modified with $\operatorname{In}_{2} \mathrm{~S}_{3}$ and ThLc dark (3a) and illuminated (3b). Scan rate was $20 \mathrm{mV} / \mathrm{s}$. 
Inset: Potentiometric signal recorded by the oxygen sensor while scanning $3 \mathrm{a}$ and $3 \mathrm{~b}$ CVs.

XRD diffractograms were measured for the electrodes at different building stages: an FTO electrode, FTO- $\mathrm{In}_{2} \mathrm{~S}_{3}$ electrode before and after $1 \mathrm{~V}$ voltage vs. SHE was applied during $360 \mathrm{~s}$, and $\mathrm{In}_{2} \mathrm{~S}_{3}$ before its addition to FTO, Figure S1. The peaks that characterize either FTO or $\operatorname{In}_{2} \mathrm{~S}_{3}$ remain unchanged in their $2 \Theta$ values in all cases, although their intensity varies. The diffractograms also show that new diffraction peaks do not appear after application of $1 \mathrm{~V}$ to FTO- $\mathrm{In}_{2} \mathrm{~S}_{3}$ electrodes that could be attributed to the appearance of oxysulfides or any other possible oxidation product.

The electrical response of FTO, FTO- $\mathrm{In}_{2} \mathrm{~S}_{3}$ and FTO- $\mathrm{In}_{2} \mathrm{~S}_{3}$ ThLc electrodes was followed by cyclic voltammetry under dark and illumination conditions. On the one hand, the FTO$\mathrm{In}_{2} \mathrm{~S}_{3}-\mathrm{ThLc}$ electrodes, on which the laccase was physically deposited, did not increase the electrochemical response provided by a FTO- $\mathrm{In}_{2} \mathrm{~S}_{3}$ electrode under illumination, Figure 3. On the other hand, the FTO- $\mathrm{In}_{2} \mathrm{~S}_{3}$-ThLc electrodes, on which the enzyme was covalently immobilized, behaved different, Figure 4. For potentials higher than $0.8 \mathrm{~V}$ vs SHE both bare FTO and FTO- $\operatorname{In}_{2} \mathrm{~S}_{3}$ gave a current increase when illuminating the electrodes much smaller than the FTO- $\mathrm{In}_{2} \mathrm{~S}_{3}$-ThLc ones, which increased more than 10-fold when illuminated (Figure 4). The $\mathrm{O}_{2}$ microsensor placed ca. $1.5 \mathrm{~mm}$ away from the photoelectroactive surface detected $\mathrm{O}_{2}$ produced by the FTO$\mathrm{In}_{2} \mathrm{~S}_{3}$-ThLc electrode only when it was illuminated, Figure 4 inset. These results indicate that covalent attachment of ThLc on the semiconductor surface is needed to oxidize $\mathrm{H}_{2} \mathrm{O}$ to $\mathrm{O}_{2}$.

The detection of $\mathrm{O}_{2}$ by the sensor started as the backwards scan of the $\mathrm{CV}$ was initiated, suggesting that $\mathrm{O}_{2}$ production by the illuminated FTO- $\mathrm{In}_{2} \mathrm{~S}_{3}-\mathrm{ThLc}$ electrode took place at the higher potentials. A delay in the sensor signal is expected due to the diffusion time needed for the photobioelectrochemically produced $\mathrm{O}_{2}$ to diffuse towards the sensor.

In order to determine at which redox potential $\mathrm{O}_{2}$ started its evolution at the FTO- $\operatorname{In}_{2} \mathrm{~S}_{3}$-ThLc electrode and to increase the magnitude of its detection, 5 min chronoamperometric measurements under dark and illumination conditions in presence of the $\mathrm{O}_{2}$ sensor was performed, Figure 5. A typical FTO- $\operatorname{In}_{2} \mathrm{~S}_{3}$ electrode provided a photocurrent increase due to illumination that yielded $0.262 \mathrm{mC}$ charge at $1 \mathrm{~V}$ over $150 \mathrm{~s}$, although the $\mathrm{O}_{2}$ sensor did not give any significant signal change during the event, Figure 5A. The FTO- $\operatorname{In}_{2} \mathrm{~S}_{3}$-ThLc electrode behaved differently, viz. the photocurrent increase at $1 \mathrm{~V}$ was more intense, yielding $0.496 \mathrm{mC}$ over nearly the same time period, while the $\mathrm{O}_{2}$ detected was significant. These results support the previous ones showing that covalent attachment of ThLc on the semiconductor surface is needed to oxidize $\mathrm{H}_{2} \mathrm{O}$ to $\mathrm{O}_{2}$.

Although the $\mathrm{O}_{2}$ sensor provides evidence of $\mathrm{H}_{2} \mathrm{O}$ oxidation catalyzed by a photoelectroenzymatic process, there are many factors hindering the quantification of the $\mathrm{O}_{2}$ produced, specifically: i) the $\mathrm{O}_{2}$ present in the solution is not homogeneously distributed during the experimental timescale, as it is produced in the electrode surface and the solution is quiescent; ii) not all the $\mathrm{O}_{2}$ produced diffuses to or through the sensor; iii) the $\mathrm{O}_{2}$ in solution equilibrates with the gas phase. All these reasons explain why only transient $\mathrm{O}_{2}$ signals were measured during chronoamperometric studies, as well as the delay of approximately $30 \mathrm{~s}$ for the onset detection. The signal delay was attributed to $\mathrm{O}_{2}$ diffusion limitations (supporting information). A correlation could be established between the $\mathrm{O}_{2}$ produced by an equivalent FTO surface at different overpotentials where $\mathrm{H}_{2} \mathrm{O}$ oxidation takes place and the $\mathrm{O}_{2}$ signal detected by the sensor when located exactly at the same position with respect to the electrode as in the photoelectrochemical measurements. The correlation was based on the results shown in Figures S2 and $\mathrm{S} 3 \mathrm{~A}$, which indicate that the integration of the sensor signal over time correlates linearly with the charge measured during the associated FTO chronoamperometric experiments. On the other hand, the extent of $\mathrm{H}_{2} \mathrm{O}$ oxidation to the byproduct $\mathrm{H}_{2} \mathrm{O}_{2}$ by the FTO electrodes biased at different potentials was also analyzed. An aliquot of the resulting electrolyte was taken and HRP and ABTS were added to it for $\mathrm{H}_{2} \mathrm{O}_{2}$ determination. The negligible ABTS oxidation detected spectrophotometrically at $414 \mathrm{~nm}$ implied a negligible $\mathrm{H}_{2} \mathrm{O}_{2}$ formation at any applied potential (Figure $\mathrm{S} 3 \mathrm{~B}$ ), and consequently made clear that all charge was used essentially to produce $\mathrm{O}_{2}$.
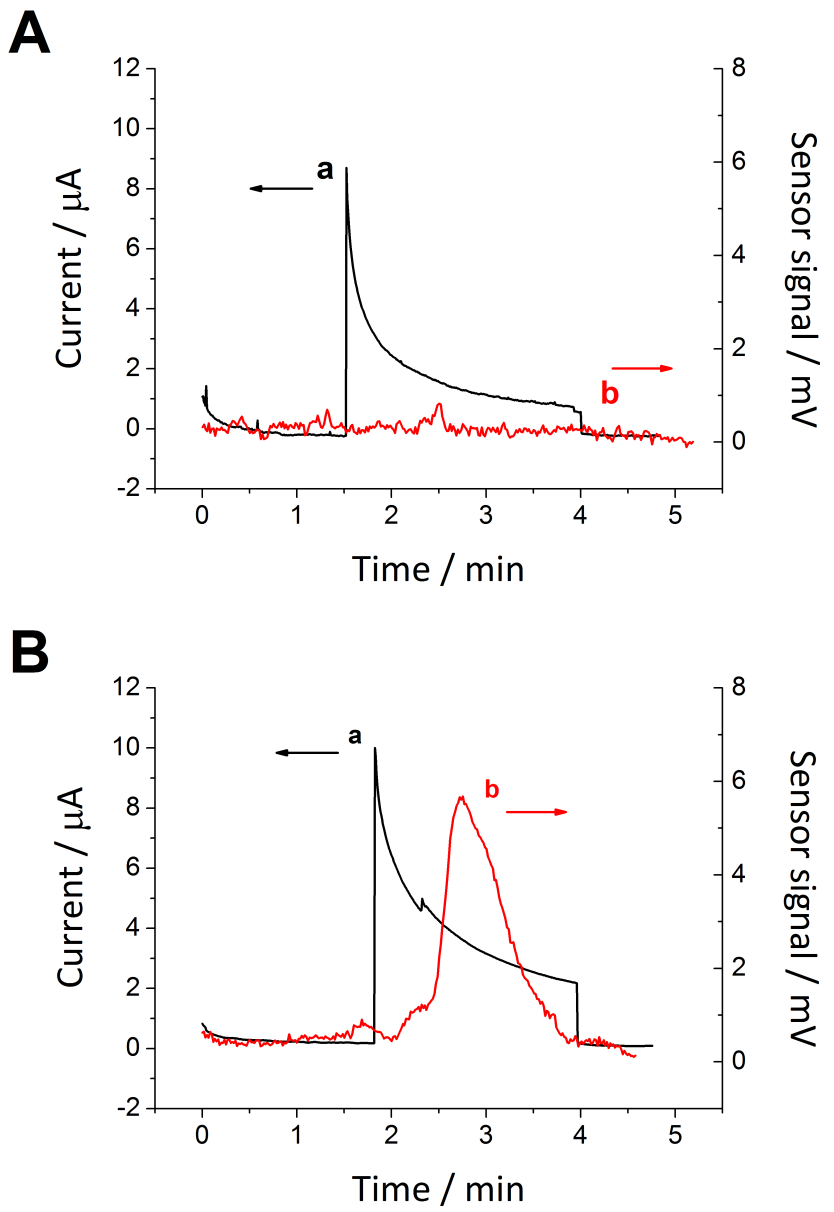

Figure 5. (A) Chronoamperogrammes recorded at $1 \mathrm{~V}$ vs. SHE on an FTO- $\operatorname{In}_{2} \mathrm{~S}_{3}$ electrode (a), illuminating from 1.5 to 4 min. (b) $\mathrm{O}_{2}$ signal measured by the sensor. (B) Chronoamperometry recorded at $1 \mathrm{~V}$ vs SHE on an FTO- $\operatorname{In}_{2} \mathrm{~S}_{3}$-ThLc electrode (a), illuminating from 1.8 to 4 min. (b) $\mathrm{O}_{2}$ signal measured by the sensor.

The calibration performed allowed studying the $\mathrm{O}_{2}$ produced by a FTO- $\operatorname{In}_{2} \mathrm{~S}_{3}$-ThLc electrode when illuminated during 6 min at different bias potentials. A bias potential of $0.7 \mathrm{~V}$ vs. SHE yielded no measurable $\mathrm{O}_{2}$ signal, whereas in the case of $0.8-1.0 \mathrm{~V}$ potential range the amount of $\mathrm{O}_{2}$ produced by the electrode could be estimated (Table 1). The current increase at 
higher overpotential provided a higher and more reproducible $\mathrm{O}_{2}$ production. A faradaic yield of $45 \pm 5 \%$ is obtained at $1 \mathrm{~V}$ from the ratio between the amount of $\mathrm{O}_{2}$ produced and the charge measured at the electrode during the chronoamperommetry under light illumination. With the same calibration the amount of $\mathrm{O}_{2}$ produced in the experiment of Fig. 5B was equivalent to $0.22 \mathrm{mC}$, which means that, in comparison with the result in Fig. 5A, the additional charge transferred in the presence of the enzyme $(0.23 \mathrm{mC})$ corresponds almost completely to water oxidation to $\mathrm{O}_{2}$.

A control experiment was done with ThLc covalently bound to the functionalized FTO to evaluate at which redox potential the enzyme was able to evolve $\mathrm{O}_{2}$ without photochemical excitation. Without illumination the $\mathrm{O}_{2}$ production was not detected until $1.55 \mathrm{~V}$ was applied at the electrode (Fig. S4), which was the same potential required for measuring nonbiocatalytic water oxidation directly at the bare FTO electrode (Figure S2)

Table 1. Charge and amount of $\mathrm{O}_{2}$ produced by illuminated FTO- $\operatorname{In}_{2} \mathrm{~S}_{3}$-ThLc electrodes under different applied potentials during $6 \mathrm{~min}$. Each measure was recorded with a freshly prepared electrode.

\begin{tabular}{|c|c|c|c|}
\hline $\mathrm{E}(\mathrm{SHE}) / \mathrm{V}$ & Charge $(\mathrm{mC})$ & $\mathrm{O}_{2}(\mathrm{nmol})$ & $\begin{array}{c}\text { Faradaic } \\
\text { yield }(\%)\end{array}$ \\
\hline 0.7 & $0.3 \pm 0.1$ & 0 & 0 \\
\hline 0.8 & $0.7 \pm 0.1$ & $0.5 \pm 0.1$ & $30 \pm 5$ \\
\hline 0.9 & $0.6 \pm 0.2$ & $0.44 \pm 0.03$ & $30 \pm 10$ \\
\hline 1.0 & $0.8 \pm 0.2$ & $0.93 \pm 0.04$ & $45 \pm 5$ \\
\hline
\end{tabular}

The amount of active laccase immobilized on the FTO$\mathrm{In}_{2} \mathrm{~S}_{3}$-ThLc electrodes was estimated by the standard ABTS oxidation assay monitored by UV-VIS spectroscopy, which allows determining the amount of active enzyme from the rate of ABTS oxidation (in the presence of $\mathrm{O}_{2}$ ). ${ }^{60}$ First a calibration with different free ThLc concentrations ranging from 2.3 $\mathrm{ng} / \mathrm{mL}$ to $140 \mathrm{ng} / \mathrm{mL}$ was performed (Figure S5), then different modified electrodes were placed in the side of an UV-VIS cuvette, and their ABTS oxidation activity was tested, Figure 6. The ThLc remained active after its covalent immobilization on either sulfide-loaded or FTO electrodes (Figure 6a and 6b). The average amount of the active enzyme on 4 different FTO$\mathrm{In}_{2} \mathrm{~S}_{3}$-ThLc electrodes was measured in this way from the UVVis spectroscopy data of the oxidized ABTS and found to be $0.18 \pm 0.08 \mu \mathrm{g}$. However, after being simultaneously exposed to a positive potential and illumination, its activity dropped drastically, losing $99 \%$ of the initial value (Figure $6 \mathrm{~d}$ and e). A sample from the electrolyte solution was measured to check if ThLc leaked during the operation. No active enzyme was detected in the solution (Figure 6c).

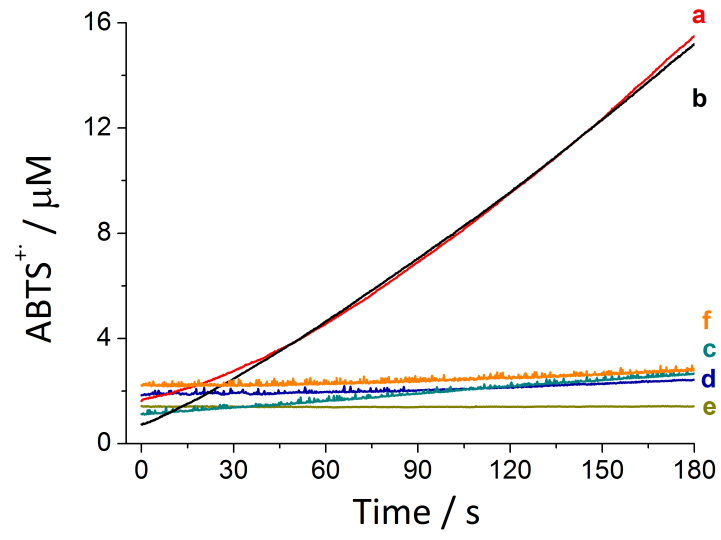

Figure 6 ABTS oxidation kinetics catalyzed by ThLc immobilized on FTO electrodes. (a) Freshly prepared FTO-ThLc electrode. (b) Freshly prepared FTO- $\mathrm{In}_{2} \mathrm{~S}_{3}$-ThLc electrode. (c) Test made to detect any enzyme leaked into solution from FTO- $\operatorname{In}_{2} \mathrm{~S}_{3}$ ThLc electrode after 6 min of photochronoamperometry at $0.8 \mathrm{~V}$ vs. SHE. (d) FTO-ThLc electrode after 6 min photochronoamperometry at $0.8 \mathrm{~V}$ vs. SHE). (e) FTO- $\mathrm{In}_{2} \mathrm{~S}_{3}$-ThLc electrode after 6 min photochronoamperometry at $0.8 \mathrm{~V}$ vs. SHE. (f) FTO-ThLc electrode illuminated during 6 min with no applied potential. ABTS $^{+\cdot}$ concentration was measured spectrophotometrically at $414 \mathrm{~nm}$.

The ThLc stability against illumination was also measured by illuminating during $6 \mathrm{~min}$ in open circuit conditions a FTO/ThLc electrode. The average enzyme activity after the illumination was $7.5 \pm 0.1 \mathrm{ng}$ (Figure 6f), which is comparable to the activity measured on the electrodes after the photobioelectrochemical experiments. These control experiments allow attributing the laccase inactivation to the Xe lamp illumination.

Additional control experiments were performed to determine the enzyme sensitivity to the lamp illumination. The activity in open circuit conditions of FTO-ThLc after illumination with the Xe lamp through three filters $(\lambda \geq 400 \mathrm{~nm}, \lambda \geq$ $495 \mathrm{~nm}, 420 \leq \lambda \leq 480 \mathrm{~nm}$ ) was measured, finding out that the ABTS oxidation activity was reduced to $10 \%, 17 \%$ and $30 \%$, respectively (Figure S6). The photoelectrochemical response and the $\mathrm{O}_{2}$ production was also measured for these filtered samples, registering $\mathrm{O}_{2}$ only in the case of $\lambda \geq 400 \mathrm{~nm}$ allowed light. The light intensity was measured for all the exposed filtering configurations (Table S1). An approximate quantum yield of $0.5 \%$ was calculated for the case of FTO- $\mathrm{In}_{2} \mathrm{~S}_{3}-\mathrm{ThLc}$ illumination with $\lambda$ centered at $450 \mathrm{~nm}$. The UV-Vis transmittance of the polycarbonate, band and cut-off filters used was measured, Figure S7.

Copper has been described as an $\mathrm{O}_{2}$ evolution electrocatalyst $^{5,67}$. Therefore we considered that an undesired enzyme denaturalization might take place that releases from its active site $\mathrm{Cu}$ cations, which might adsorb on $\mathrm{In}_{2} \mathrm{~S}_{3}$ and lead to $\mathrm{O}_{2}$ evolution. Three control experiments adding to FTO- $\operatorname{In}_{2} \mathrm{~S}_{3}$ electrodes instead of laccase an amount of $\mathrm{CuSO}_{4}$ equivalent to the amount of $\mathrm{Cu}$ in the laccase yielded no $\mathrm{O}_{2}$ detection upon illumination and $1.0 \mathrm{~V}$ vs SHE applied voltage, Figure S8. This control hints that the laccase structure, not $\mathrm{Cu}$ ions formed by its photodecomposition, is involved in the $\mathrm{O}_{2}$ evolution obtained with FTO- $\mathrm{In}_{2} \mathrm{~S}_{3}$-ThLc electrodes. 


\section{Discussion}

The formation of hybrid inorganic/biochemical photoelectrocatalysts by attachment of enzymes to semiconductor materials based electrodes has been shown for only few redox metalloenzymes, such as a hydrogenase ${ }^{68}$ or a $\mathrm{CO}$ dehydrogenase. ${ }^{69}$ Adsorption of a laccase to p-type silicon on a gold electrode has been reported for photoelectrochemical reduction of $\mathrm{O}_{2}{ }^{70}$ However, the photoelectrocatalytic properties of the hybrid device were considerably worse than those obtained with high redox potential laccases directly attached to electrodes $^{41}$, which give high catalytic currents of $\mathrm{O}_{2}$ bioelectroreduction at low overpotentials accompanied with a high operational stability. ${ }^{44-49}$

Therefore, it is of much interest to develop laccase/semiconductor hybrids as photoelectrocatalysts devices for the reverse reaction, i.e. water oxidation to $\mathrm{O}_{2}$. This process still requires the development of efficient catalysts based on cheap metals. The use of copper complexes as electrochemical catalysts for $\mathrm{H}_{2} \mathrm{O}$ oxidation has been proven, ${ }^{67,54}$ as has the use of copper-containing redox enzymes such as laccase ${ }^{41,43,44}$ and bilirubin oxidase. ${ }^{44,50}$ Although the overpotential shown by copper complexes is very promising, the use of an extra energy provided by the light may help to reduce the energy to invest in the process. The $\operatorname{In}_{2} \mathrm{~S}_{3}$ semiconductor is able to absorb visible light, and has shown ability to transfer the lightexcited electrons to a hydrogenase enzyme in presence of a sacrificial electron donor so that the enzyme reduces protons to $\mathrm{H}^{62} \mathrm{In}_{2} \mathrm{~S}_{3}$ may be also coupled to electrodes to promote oxidative reactions, as the excited electrons can be swiftly transferred to the positively polarized electrode before recombination. ${ }^{53}$ Hence, immobilizing the laccase on the surface of the $\mathrm{In}_{2} \mathrm{~S}_{3}$ modified electrode can take the advantage of the light energy to reduce the applied potential needed for $\mathrm{H}_{2} \mathrm{O}$ electrooxidation. Taking into account that the valence band level of $\mathrm{In}_{2} \mathrm{~S}_{3}$ lies below the standard potential for $\mathrm{H}_{2} \mathrm{O}$ oxidation ${ }^{52}$, the photogenerated hole is suitable to accept the electrons from $\mathrm{H}_{2} \mathrm{O}$ molecules, if coupled with an adequate catalyst.

The $\mathrm{O}_{2}$ production by the FTO- $\mathrm{In}_{2} \mathrm{~S}_{3}$-ThLc system requires a lower electric energy input thanks to the light assistance. The

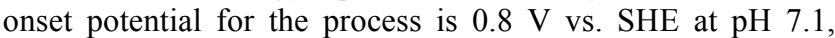
which corresponds to $1.24 \mathrm{~V}$ vs. RHE. Therefore, the hybrid photoelectrocatalyst is able to oxidize water to $\mathrm{O}_{2}$ with $30 \%$ faradaic efficiency at practically the theoretical thermodynamic potential value; it should be noted that the theoretical potential value considers $\mathrm{P}\left(\mathrm{O}_{2}\right)=1 \mathrm{Atm}$, and we are measuring at much lower partial pressure, specialty at $t=0$. The same laccase attached to porous graphite electrode did not produce $\mathrm{O}_{2}$ below $1.2 \mathrm{~V}$ vs. SHE at the same $\mathrm{pH}^{41}$ thus the photoelectrochemical strategy allows the reduction of the overpotential for $\mathrm{H}_{2} \mathrm{O}$ electrooxidation by at least $0.4 \mathrm{~V}$. When the enzyme is covalently bound directly to an FTO electrode, $\mathrm{O}_{2}$ production is negligible below the redox potential, at which water is oxidized directly at the FTO $(1.55 \mathrm{~V})$. This result can be explained by the hindrance of establishing direct electron transfer of the laccase at a less rough and conductive electrode than low density graphite. ${ }^{41}$ Instead, the porous surface of the $\operatorname{In}_{2} \mathrm{~S}_{3}$ favors the electron transfer to the redox sites of the attached laccase molecules under light illumination, as has been previously observed for another enzyme, hydrogenase. ${ }^{62}$ In the present case, covalent binding of the enzyme to the functionalized semiconductor was required, possibly because the smaller size of the laccase molecules than the hydrogenase ones pre- vents their retention in the $\operatorname{In}_{2} \mathrm{~S}_{3}$ pores just by adsorption. Another possible explanation is that hydrogenase was stabilized by S-S attracting interactions between the chalcogenide's surface and the distal cluster of the enzyme,${ }^{62}$ whereas in this work laccase lacks any surface motif to promote a strong and oriented adhesion by simple non-covalent adsorption.

As derived from the results with filtered light it seems that not all the photons able to promote electrons to the conduction band generate holes with such a low energy to allow the $\mathrm{O}_{2}$ evolution catalyzed by the laccase. Despite that the light absorption onset for $\mathrm{In}_{2} \mathrm{~S}_{3}$ is $\lambda \leq 600 \mathrm{~nm},{ }^{62}$ it was needed to allow the photons with $\lambda \geq 400 \mathrm{~nm}$ to obtain a measurable $\mathrm{O}_{2}$ production (Fig. S6). Photons with $\lambda \geq 495 \mathrm{~nm}$ did not drive $\mathrm{O}_{2}$ evolution although the light power reaching the FTO-ThLc electrode was high enough (Table S1). A possible explanation is that higher energy photons are able to generate hot carriers, which may be the responsible of promoting the photobiocatalytic process. The fact that the amount of $\mathrm{O}_{2}$ generated using the $420 \leq \lambda \leq 480 \mathrm{~nm}$ filter is much smaller than that found with the $\lambda \geq 400 \mathrm{~nm}$ filter (Figs. S6D and S6B respectively) may be due to the significantly lower amount of photons hitting the electrode in the first case (see Fig. S7).

The faradaic yield of the FTO- $\mathrm{In}_{2} \mathrm{~S}_{3}$-ThLc device increases to $45 \%$, when the electrode is polarized at $1 \mathrm{~V}$, which is comparable to the faradaic efficiencies reported for some inorganic photoelectrocatalysts for $\mathrm{O}_{2}$ production. ${ }^{71}$ The photocurrent measured at $1 \mathrm{~V}$ in the control FTO- $\operatorname{In}_{2} \mathrm{~S}_{3}$ electrode without laccase is approximately $53 \%$ of that for the FTO- $\mathrm{In}_{2} \mathrm{~S}_{3}-\mathrm{ThLc}$ electrode (Fig. 5), suggesting that the main cause that decreases the faradaic yield of the later system for $\mathrm{O}_{2}$ production is the photocorrosion of the $\operatorname{In}_{2} \mathrm{~S}_{3}{ }^{53}$ Still, we can note that the amount of charge transferred in the experiment of Fig. 5A, considering the amount of $\operatorname{In}_{2} \mathrm{~S}_{3}$ on the electrode active area $(\sim 20 \mu \mathrm{g})$ and the specific surface of the material $\left(\approx 40 \mathrm{~m}^{2} / \mathrm{g}\right)$, is equivalent to $\approx 2.0$ holes $/ \mathrm{nm}^{2}$ part of which might be accumulated on the surface by a capacitance effect, not by a redox process; the extent of sulphide photocorrosion in these experiments must be therefore limited. Detection of such low photocorrosion rates is beyond the detection limits of most analytical techniques.

A benchmark for biophotoelectrocatalytic $\mathrm{O}_{2}$ production has been reported by Reisner and co-workers using photosystem II (PSII) immobilized within a Os complex redox polymer on nanostructured ITO electrodes. ${ }^{37}$ High photocurrents up to 410 $\mu \mathrm{A} \mathrm{cm}^{-2}$ at $0.5 \mathrm{~V}$ vs. SHE have been reported with $85 \%$ faradaic efficiency. However, the photocurrents measured with PSII decrease two orders of magnitude, when working in direct electron transfer mode, i.e. in the absence of the redox polymer that shuttles electrons between the redox centers of PSII and the electrode. ${ }^{40}$ In our system we measure photocurrents up to $50 \mu \mathrm{A} \mathrm{cm}^{-2}$ (at $1 \mathrm{~V}$ ) in direct electron transfer mode. Considering the determined amount of active laccase immobilized on the photoanode, its turnover frequency for $\mathrm{O}_{2-}$ production is on average $4.6 \pm 0.1 \mathrm{~s}^{-1}$, which equals that measured for PSII. ${ }^{37}$ Therefore, high photocurrents as those measured with PSII could be obtained, if the enzyme coverage was increased by using a nanostructured ITO electrode instead of the planar FTO electrodes and/or the FTO coverage with the $\mathrm{In}_{2} \mathrm{~S}_{3}$ were more homogeneous. Indeed, PSII is able to evolve $\mathrm{O}_{2}$ with the same turnover frequency at $0.5 \mathrm{~V}$ lower potential, but it has to be taken into account that PSII is nature's evolved catalyst for water oxidation, whereas the natural activity of 
laccases is the reverse reaction. Thus, adequate design of the photoelectrocatalytic device allows driving the enzymatic reaction with the aid of light to the desired direction, even if this reaction is not the thermodynamically or kinetically favored one under the standard conditions for this enzyme.

One of the main concerns for the solar system including biodevices is the photocurrent decrease with time, which could originate from different sources, such as degradation of the sulfide, the enzyme, or any of the interfaces. The surface of FTO is stable enough, so it can be excluded as cause of the low operational stability. Monitoring of the XRD pattern of $\mathrm{In}_{2} \mathrm{~S}_{3}$ before and after the photochemical water oxidation process gave no hint of indium traces of oxysulfides or oxides. The specific native activity of the biocatalyst was reduced by a factor of $99 \%$ after 6 min operation under illumination, either attached to the electrode or free in solution. This inactivation may be attributed (i) to the attack of the hydroxyl radicals formed from the photogenerated holes ${ }^{72}$ to the copper cations at the enzyme's active site, which blocks the enzyme and/or (ii) to the photodegradation of the enzyme under high power illumination. The second explanation is in agreement with our experimental result shown in Figure 6f, where a freshly prepared electrode FTO-ThLc lost any $\mathrm{O}_{2}$ reducing/ABTS oxidizing catalytic activity after illumination, even if it was never connected to the electrochemical setup. We tested the system illuminated with filtered light, finding out that damage to laccase molecules occurred in the whole visible range and it increased with the light intensity. Nevertheless, it may be possible that the $\mathrm{O}_{2}$-evolution activity of the laccase under irradiation is less unstable than its $\mathrm{O}_{2}$-reduction activity with ABTS as substrate, as previous electrocatalytic studies suggested that the $\mathrm{Cu}$ T1 site (where ABTS reacts with the enzyme) is not involved in the former activity. ${ }^{41}$

\section{Conclusions}

ThLc has been successfully presented as catalyst for $\mathrm{O}_{2}$ evolution in combination with $\operatorname{In}_{2} \mathrm{~S}_{3}$ particles deposit on FTO transparent electrode to assemble a light-assisted photoelectrochemical anode. The turnover frequency per enzyme molecule given by the FTO- $\mathrm{In}_{2} \mathrm{~S}_{3}$-ThLc system is comparable to the best-reported photobioelectrochemical system, ${ }^{37}$ opening a route for future much-needed improvement. Such improvement may come by using nanostructured ITO electrodes for obtaining higher enzyme coverage and by obtaining mutant laccases with higher operational stability under light illumination and/or turnover towards $\mathrm{O}_{2}$ evolution. Directed evolution has shown previously to be a successful strategy to obtain mutated laccases with enhanced properties and activity in harder environments, such as neutral $\mathrm{pH}$ or organic solvents, ${ }^{73,74}$ and may yield more appropriate biocatalysts. The use of intermediate-band semiconductors may also improve the fraction of the solar energy spectrum able to drive the photo-induced chemical change, allowing low-energy photons to add their energy and pump electrons to the conductive band. $^{53,63}$

\section{ASSOCIATED CONTENT}

\section{Supporting Information}

XRD characterization of modified electrodes, FTO non-catalytic $\mathrm{O}_{2}$ evolution measurements, $\mathrm{O}_{2}$ evolution calibrations, and exper- iments with filtered light are included as Supporting Information. The Supporting Information is available free of charge on the ACS Publications website.

\section{AUTHOR INFORMATION}

\section{Corresponding Author}

* Marcos Pita: marcospita@icp.csic.es; Antonio L. De Lacey: alopez@icp.csic.es. Instituto de Catalisis y Petroleoquímica, CSIC. C/ Marie Curie, 2. L10 28049 Madrid, Spain.

\section{Funding Sources}

This work was funded by the Spanish MINECO/FEDER projects CTQ2015-71290-R and ENE2013-46624-C4-1-R, the CSIC PIE 2015601018 project and by the European Commission project "Bioenergy" FP7-PEOPLE-2013-ITN-607793. C.T. scholarship is funded by the Spanish MINECO contract BES-2013-064099.

\section{REFERENCES}

(1) Fujishima, A.; Honda, K. Bull. Chem. Soc. Japan 1971, 44, 1148-1150.

(2) Fujishima, A.; Honda, K. Nature 1972, 238, 37.

(3) Li, X.; Yu, J.; Low, J.; Fang, Y.; Xiao, J.; Chen, X. J. Mater Chem. A 2015, 3, 2485-2534.

(4) Lewis, N. S.; Nocera, D. G. Proc. Natl. Acad. Sci. U.S.A. 2006, 103, 15729-15735.

(5) House, R. L.; Iha, N. Y. M.; Coppo, R. L.; Alibabaei, L.; Sherman, B. D.; Kang, P.; Brennaman, M. K. Hoertz, P. G.; Meyer, T. J. J Photochem. Photobiol. C: Photochem. Rev. 2015, 25, 32-45.

(6) Lewis, N. S. Science 2016, 351, 353.

(7) White, J. L.; Baruch, M. F.; Pander III, J. E.; Hu, Y.; Fortmeyer, I. C.; Park, J. E.; Zhang, T.; Liao, K.; Gu, J.; Yan, Y. et al. Chem. Rev. 2015, 115, 12888-12935.

(8) Beck, F.; Gerischer, H. Z. Elektrochem. 1959, 63, 943-950.

(9) Green, M. Modern Aspects of Electrochemistry 1959, 2, 343407.

(10) Gerischer, H. J. Electrochem. Soc. 1966, 113, 1174.

(11) Lohmann, F. Ber. Bunsenges. Phys. Chem. 1966, 70, 87-92.

(12) Renz, C. Helv. Chim. Acta 1921, 4, 961-968.

(13) Yamamoto, M.; Tanaka, K. ChemPlusChem 2016, 81, 10281044.

(14) Sprick, R.S.; Jiang, J.-X.; Bonillo, B.; Ren, S.; Ratvijitvech, T.; Guiglion, P.; Zwijnenburg, M.A.; Adams, D.J.; Cooper, A.I. $J$. Am. Chem. Soc. 2015, 137, 3265-3270.

(15) Amao, Y. ChemCatChem 2011, 3, 458-474.

(16) Babu, V.J.; Vempati, S.; Uyar, T.; Ramakrishna, S. Phys. Chem. Chem. Phys. 2015, 17, 2960-2986

(17) Kubacka, A.; Fernández-García, M.; Colón, G. Chem. Rev. 2012, 112, 1555-1614

(18) Sivula, K.; Van de Krol, R. Nat. Rev. Materials 2016, 1, 15010

(19) Trasatti, S. J. Electroanal. Chem. 1980, 111, 125-131.

(20) Lee, Y.; Suntivich, J.; May, K. J.; Perry, E. E.; Shao-Horn, Y. J. Phys. Chem. Lett. 2012, 3, 399-404.

(21) Walter, M. G.; Warren, E. L.; McKone, J. R.; Boettcher, S. W.; Mi, Q.; Santori, E. A.; Lewis, N. S. Chem. Rev. 2010, 110, 64466473.

(22) McCrory, C. C. L.; Juong, S.; Peters, J. C.; Jaramillo, TF. J. Am. Chem. Soc. 2013, 135, 16977-16987.

(23) Matheu, R.; Francas, L.; Chernev, P.; Ertem, M. Z.; Batista, V.S.; Haumann, M.; Sala, X.; Llobet, A. ACS Catal. 2015, 5, 34223429.

(24) Doyle, R. L.; Godwin, I. J.; Brandon, M. P.; Lyons, M. E. G. Phys. Chem. Chem. Phys. 2013, 15, 13737-13783.

(25) Corrigan, D. A. J. Electrochem. Soc. 1987, 134, 377-384.

(26) Trotochaud, L.; L.; Young, S. L.; Ranney, J. K.; Boettcher, S. W. J. Am. Chem. Soc. 2014, 136, 6744-6753. 
(27) Zhang, B.; Zheng,X.; Voznyy, O.; Comin, R.; Bajdich,M.; García-Melchor, M.; Han, L.; Xu, J,; Liu, M.; Zheng, L. et al. Science 2016, 352, 333-337.

(28) Kanan, M. W.; Nocera, D. G. Science 2008, 321, 1072-1075.

(29) Soriano-López, J.; Goberna-Ferroón, S.; Vigara, L.; Carbó, J. J.; Poblet, J.M.; Galán-Mascarós, J.R. Inorg. Chem. 2013, 52, 4753-4755

(30) Najafpour, M.M.; Renger, G.; Hołyńska, M.; Moghaddam, A.N.; Aro, E.M.; Carpentier, R.; Nishihara, H.; Eaton-Rye, J.J.; Shen, J.R.; Allakhverdiev, S.I. Chem. Rev. 2016, 116, 2886-2936.

(31) Sun, L. Science 2015, 348, 635-636.

(32) Du, J.; Chen, Z.; Ye, S.; Wiley, B.J.; Meyer, T.J. Angew. Chem. Int. Ed. 2015, 54, 2073-2078.

(33) Garrido-Barros, P.; Funes-Ardoiz, I.; Drouet, S.; BenetBuchholz, J.; Maseras, F.; Llobet, A. J. Am. Chem. Soc. 2015, 137, 6758-6761.

(34) Najafpour, M.; Ghobadi, M.; Larkum, A.; Shen, J.; Allahkhverdiev,S. Trends Plant Sci. 2015, 20, 559-568.

(35) Badura, A.; Esper, B.; Ataka, K.; Grunwald, C.; Woll, C.; Kuhlmann, J.; Heberle, J.; Rogner, M. Photochem. Photobiol. 2006, $82,1385-1390$

(36) Yehezkeli, O.; Tel-Vered, R.; Wasserman, J.; Trifonov, A.; Michaeli, D.; Nechushtai, R.; Willner, I. Nat. Commun 2012, 3, 742.

(37) Sokol, K.; Mersch, D.; Hartmann, V.; Zhang, J.; Nowaczyk, M.; Rogner, M.; Ruff, A.; Schuhmann, W.; Plumere, N.; Reisner, E. Energy Environ. Sci. 2016, 9, 3698-3709.

(38) Alonso-Lomillo, M. A.; Rudiger, O.; Maroto-Valiente, A.; Velez, M.; Rodriguez-Ramos, I.; Munoz, F. J.; Fernandez, V. M.; De Lacey, A. L. Nano Lett. 2007, 7, 1603-1608.

(39) Leger, C; Bertrand, P. Chem. Rev. 2008, 108, 2379-2438.

(40) Kato, M.; Cardona, T.; Rutherford, A.; Reisner, E. J. Am. Chem. Soc. 2013, 135, 10610-10613.

(41) Pita, M.; Mate, D. M.; Gonzalez-Perez, D.; Shleev, S.; Fernandez, V. M.; Alcalde, M.; De Lacey, A. L. J. Am. Chem. Soc. 2014 $136,5892-5895$.

(42) Solomon, E. I.; Augustine, A. J.; Yoon, J. Dalton Trans. 2008, 3921-3932.

(43) Shleev, S.; Jarosz-Wilkolazka, A.; Khalunina, A.; Morozova, O.; Yaropolov, A.; Ruzgas, T.; Gorton, L. Bioelectrochemistry 2005, 67, 115-124.

(44) Tsujimura, S.; Kamitaka, Y.; Kano, K. Fuel Cells 2007, 7, 463-469.

(45) Blanford, C. F.; Foster, C. E.; Heath, R. S.; Armstrong, F. A. Faraday Discuss. 2008, 140, 319-335.

(46) Shleev, S.; Shumakovich, G.; Morozova, O.; Yaropolov, A. Fuel Cells 2010, 10, 726-733.

(47) Parimi, N. S.; Umasankar, Y.; Atanassov, P.; Ramasamy, R. P. ACS Catal. 2012, 2, 38-44.

(48) Lalaoui, N., Elouarzaki, K.; Le Goff, A.; Holzinger, M.; Cosnier, S. Chem. Commun. 2013, 49, 9281-9283.

(49) Di Bari, C.; Goni-Urtiaga, A.; Pita, M.; Shleev, S.; Toscano, M. D.; Sainz, R.; De Lacey, A. L. Electrochim. Acta 2016, 191, 500509 .

(50) Shleev, S.; Andoralov, V.; Pankatrov, D.; Falk, M.; Aleksejeva, O.; Blum, S. Electroanalysis 2016, 28, 2270-2287.
(51) Becker, R. S.; Zheng, T.; Elton, J.; Saeki, M. Sol. Energ. Mat. 1986, 13, 97-107.

(52) Xu, Y.; Schoonen, M. A. A. Am. Mineralogist 2000, 85, 543556.

(53) Tapia, C.; Berglund, S.P.; Friedrich, D.; Dittrich, T.; Bogdanoff, P.; Liu, Y.; Levcenko, S.; Unold, T.; Conesa, J. C.; De Lacey, A.L.; Pita, M.; Fiechter, S. J. Phys. Chem. C. 2016, 120, $28753-$ 28761.

(54) An, L.; Zhou, P.; Yin, J.; Chen, F.; Liu, H.; Du, Y.; Xi, P. Inorg. Chem. 2015, 54, 3281-3289.

(55) Tian, Y.; Wang, L.; Tang, H.; Zhou, W. J. Mater. Chem. A 2015, 3, 11294-11301.

(56) Braiek, Z.; Brayek, A.; Ghoul, M.; Ben Taieb, S.; Gannouni, M.; Ben Assaker, I.; Souissi, A.; Chtourou, R. J. Alloys Comp. 2015, $653,395-401$.

(57) Wang, L.; Xia, L.; Wu, Y.; Tian, Y. ACS Sustainable Chem. Eng. 2016, 4, 2606-2614

(58) Becker, R.S.; Zheng, T.; Elton, J.; Saeki, M. Solar Eng. Maters. 1986, 13, 97-107.

(59) Herero, J.; Ortega, J. Solar Eng. Maters.1988, 17, 357-368.

(60) Shleev, S.; Morozova, O.V.; Nikitina, O.V.; Gorshina, E.S.; Rusinova, T.V.; Serezhenkov, V.A.; Burbaev, D.S.; Gazaryan, I.G.; Yaropolov, A.I. Biochimie 2004, 86, 693-703.

(61) Bradford, M.M. Anal. Biochem. 1076, 72, 248-254.

(62) Tapia, C.; Zacarias, S.; Pereira, I. A. C.; Conesa, J. C.; Pita M.; De Lacey, A. L. ACS Catalysis, 2016, 6, 5691-5698.

(63) Lucena, R.; Aguilera, I.; Palacios, P.; Wahnón, P.; Conesa, J. C. Chem. Mater. 2008, 20, 5125-5127.

(64) Allongue, P; Delamar, M.; Desbat, B.; Fagebaume, O.; Hitmi, R.; Pinson, J, Saveant, J. M. J. Am. Chem. Soc. 1997, 119, 201-207.

(65) Pita, M.; Shleev, S.; Ruzgas, T.; Fernandez, V.M.; Yaropolov, A.I.; Gorton, L. Electrochem. Commun. 2006, 8, 747-753.

(66) Plyakov, K. M.; Federova, T. V.; Stepanova, E. V.; Cherkashin, E. A.; Kurzeev, S. A.; Strokopytov, B. V., Lamzin, V. S.; Koroleva, O. V. Acta Crystallogr. 2009, 65, 611-617.

(67) Chen, Z.; Meyer, T. Angew. Chem. Int. Ed. 2013, 52, 700-703.

(68) Bachmeier, A.; Wang, V. C. C.; Woolerton, T. W.; Bell, S.; Fontecilla-Camps, J. C.; Can, M.; Ragsdale, S. W.; Chaudhary, Y. S.; Armstrong, F. A. J. Am. Chem. Soc. 2013, 135, 15026-15032.

(69) King, P. W. Biochim. Biophys. Acta 2013, 1827, 949-957.

(70) Skorupska, K.; Lewerenz, H. J.; Berzal, P. U.; Rutkowska, I. A.; Kulesza, P. J. J. Mater. Chem. 2012, 22, 15267-15274.

(71) Alibabaei, L.; Sherman, B.; Norris, M.; Brennaman, M.; Meyer, T. Proc. Natl. Acad. Sci. USA 2015, 112, 5899-5902.

(72) Lucena, R.; Fresno, F.; Conesa, J.C. Catal. Commun. 2012, 20, 1-5.

(73) Zumarraga, M.; Bulter, T.; Shleev, S.; Polaina, J.; MartinezArias, A.; Plou, F.J.; Ballesteros, A.; Alcalde, M. Chem. Biol. 2007 14, 1052-1064.

(74) Mate, D.M.; Gonzalez-Perez, D.; Falk, M.; Kittl, R.; Pita, M.; De Lacey, A.L.; Ludwig, R.; Shleev, S.; Alcalde, M. Chem. Biol. 2013, 20, 223-231. 


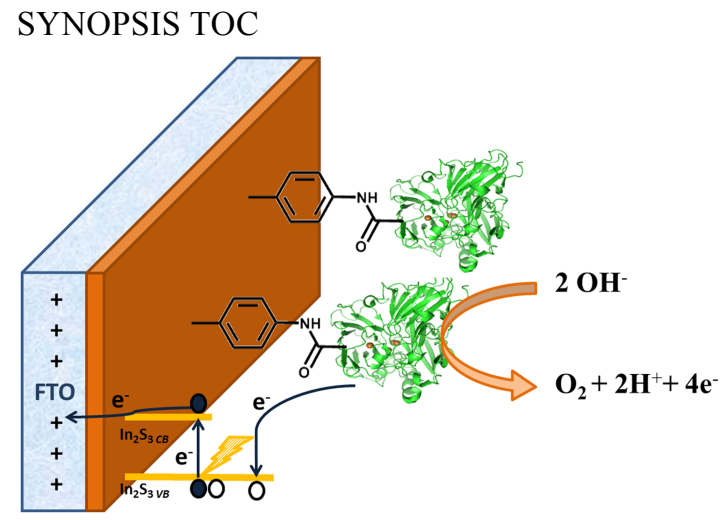

